Article

\title{
The Vulnerability of the Power Sector to Climate Variability and Change: Evidence from Indonesia
}

\author{
Kamia Handayani ${ }^{1,2, * \mathbb{C}}$, Tatiana Filatova ${ }^{1,3}$ and Yoram Krozer ${ }^{1}$ \\ 1 Department of Governance and Technology for Sustainability, University of Twente, \\ 7500 AE Enschede, The Netherlands; t.filatova@utwente.nl (T.F.); krozer@xs4all.nl (Y.K.) \\ 2 PT PLN (Persero), Jakarta Selatan 12160, Indonesia \\ 3 School of Information, Systems and Modeling, Faculty of Engineering and IT, University of Technology \\ Sydney, Sydney, NSW 2007, Australia \\ * Correspondence: k.handayani@utwente.nl
}

Received: 16 August 2019; Accepted: 21 September 2019; Published: 24 September 2019

check for updates

\begin{abstract}
The power sector is a key target for reducing $\mathrm{CO}_{2}$ emissions. However, little attention has been paid to the sector's vulnerability to climate change. This paper investigates the impacts of severe weather events and changes in climate variables on the power sector in developing countries, focusing on Indonesia as a country with growing electricity infrastructure, yet being vulnerable to natural hazards. We obtain empirical evidence concerning weather and climate impacts through interviews and focus group discussions with electric utilities along the electricity supply chain. These data are supplemented with reviews of utilities' reports and published energy sector information. Our results indicate that severe weather events often cause disruptions in electricity supply-in the worst cases, even power outages. Weather-related power outages mainly occur due to failures in distribution networks. While severe weather events infrequently cause shutdowns of power plants, their impact magnitude is significant if it does occur. Meanwhile, transmission networks are susceptible to lightning strikes, which are the leading cause of the networks' weather-related failures. We also present estimates of financial losses suffered by utilities due to weather-related power disruptions and highlights their adaptation responses to those disruptions.
\end{abstract}

Keywords: power sector; electric utility; climate change; severe weather events; climate change adaptation

\section{Introduction}

Climate change has already greatly affected economies around the world [1]. Further warming of the earth by $1.5^{\circ} \mathrm{C}$ above the pre-industrial level would entail $\$ 54$ trillion costs in damage on the global economy by the year 2100, as warned by the Intergovernmental Panel on Climate Change (IPCC) in its special report on $1.5^{\circ} \mathrm{C}$ global warming [2]. More frequent and intense extreme weather events, rising temperatures, and shifting precipitation patterns are expected to impact businesses. These have brought attention to financial institutions and credit rating agencies, which now take into account climate change risks into their assessment criteria [3,4]. Accordingly, the new international standard, i.e., ISO 14090, has emerged to assist companies in assessing climate change impacts and developing action plans for effective adaptation [5].

The power sector is not immune to climate change impacts. For example, thermal power plants are affected through acute, disruptive, extreme weather events, and gradual long-term changes in climate parameters [6]. Likewise, extreme weather events have significant impacts on the reliability and operation of electrical components of transmission and distribution (T\&D) networks [7,8]. Furthermore, extreme weather events complicate the prediction of renewable energy supply $[9,10]$. A World Bank 
report on resilient infrastructure highlights that natural shocks have caused $44 \%$ and $37 \%$ of power outages, respectively in the US between 2000 and 2017 and in Europe, between 2010 and 2017 [11]. Meanwhile, long-term changes in climate parameters, although not disruptive, can affect the quality and quantity of electricity supply and demand. For example, an increase in surface air temperature reduces the power output of gas turbine power plants [12-14] and changes in precipitation alter the reliability of hydroelectric power plants $[10,15]$.

The societal need to assure climate-resilient development has triggered scientific attention to assessing the vulnerability of the power sector to climate change. Audinet et al. discuss climate risks for the power sector and reveal the management approaches to deal with these risks taken by 12 electric utility companies operating in Canada, Taiwan, India, Australia, South Africa, and the UK. Similar studies were conducted for Asia and the Pacific [16], the European region [17], some areas of the United States $[18,19]$, and Norway [20]. Other studies focus only either on the supply or demand side: for thermal power plants [6,21,22], hydroelectric power plants [10,15,23], biofuel [23], solar power [24], wind power [25], T\&D networks [7,8], and for the electricity demand [26,27].

In general, scholars agree that thermal power plants are affected by rising air ambient and water temperatures. Similarly, renewable energy, such as wind, solar, and hydropower are also affected by climate variability and change, raising a concern on climate change mitigation and adaptation nexus. Alterations in wind speed may influence the optimal match between the wind energy source and the wind turbines power curve [28]. Moreover, increasing air temperature reduces the efficiency of solar power [29]. Moreover, extreme weather events and change in climate variables also affect the hydropower operation with uneven impacts between regions $[10,15,23]$. Similarly, impacts on electricity demand vary between regions, indicating a net decrease in demand in colder regions while on the contrary, implying a net increase in demand in warmer regions [26,27].

Most of these studies use simulation models to assess the projected climate change impacts on future electricity demand and supply. However, assessments of such effects based on empirical evidence are scarce. Moreover, current literature focuses on assessing one segment of the electricity supply chain: the power generation. Meanwhile, there is little information regarding climate change impacts on other segments of the power sector, which include transmission and distribution networks [30]. This paper contributes to covering this gap in the literature on the relationship between energy and climate change by addressing the two research questions: How do severe weather events and gradual changes in climate variable affect the entire segments of the power sector? What are the current adaptation practices taken by electric utility companies?

The paper focuses on the power sector in developing countries, which is characterized by supply shortages, aging equipment, poor performances of energy utilities, capital flow barriers, yet rapid expansions of the grid, and slow technology diffusion [30,31]. These factors reduce the reliability of the power sector and increase its vulnerability to natural shocks [11]. As such, it is already vulnerable to present-day weather and climate, let alone future climate [32].

Moreover, developing countries have a low adaptive capacity (following IPCC, we define adaptive capacity as "the combination of the strengths, attributes, and resources available to an individual, community, society, or organization that can be used to prepare for and undertake actions to reduce adverse impacts, moderate harm, or exploit beneficial opportunities" [33])—socially, technologically, and financially [34]. Hence, climate change impacts might undermine the vital role of the power sector in allowing socio-economic development that is so crucial for enabling any progress along the United Nations Sustainable Development Goals in these countries. At the same time, the IPCC's fifth assessment report highlights the scarcity of literature on climate change vulnerability, impacts, and adaptation in developing countries [35]. By taking Indonesia as a case study, we investigate the historical effects of severe weather events and gradual changes in climate variables on the power sector and estimate the losses suffered by electric utility companies due to weather-and climate-related electricity supply disruptions. Furthermore, we identify adaptation measures already taken by electric utilities to deal with those disruptions. We rely on fieldwork conducted from February to March 2018 
in Indonesia, which comprised of interviews, focus group discussions (FGD), and reviews of utilities' internal reports and published energy sector information.

This paper makes several original contributions to the literature. Firstly, it is among the first attempts to thoroughly examine the historical impacts of severe weather events and change in climate variables on all segments along the power sector supply chain and identifies adaptation measures taken by electric utilities. Hence, this paper provides new data that add to our understanding concerning weather and climate impacts on the production, transmission, and distribution of electricity and offers some important insights into firms' capacity to adapt to the changing climate. Secondly, this paper complements the modeling-based literature with empirical data on the impacts of weather-and climate-related events, their costs, and adaptation practices, which is usually scarce. Finally, this paper focuses on the power sector in a developing country, thereby adding to the scarce literature on climate change impacts, adaptation, and vulnerability of the sector in developing countries.

The remaining part of the paper proceeds as follows: Section 2 provides an overview of the case study; Section 3 presents the methodology; Section 4 discusses our findings; Section 5 draws conclusions and describes policy implications.

\section{Overview of the Case Study}

Indonesia is one of the world's fast-developing economies [36]. The Government of Indonesia is promoting an average of $5 \%$ economic growth per annum to reduce the poverty rate below $4 \%$ by 2025 [37]. Meanwhile, to date, more than 14 million Indonesians do not have electricity access [38]. Moreover, electricity consumption per capita of Indonesia is relatively low, i.e., 870 kilowatt-hours in 2016, much lower compared the 3110 kilowatt-hours of the world's average per capita consumption in the same year [39]. These imply that the demand for electricity in Indonesia will continue to grow in the next decades.

The structure of Indonesia's electricity sector is vertically integrated: the state-owned electricity company (PLN) monopolizes the retail electricity sale and is the sole purchaser of electricity produced by independent power producers (IPPs). PLN solely owns and operates T\&D networks. Meanwhile, the power generation assets are divided between PLN, its subsidiaries, and IPPs.

Due to the fact that it is an archipelagic state, the electricity infrastructures spread into eight major electricity grids and more than 600 isolated grids distributed throughout the archipelago [40]. It is pertinent to note that while the physical infrastructure spreads throughout the Indonesian archipelago, most power generation capacity $(65 \%)$ is situated in the Java and Bali islands (Table 1$)$. These islands are the most populated islands inhabited by over 148 million people, which comprises $57 \%$ of the national population [41]. The electricity consumption on these islands continues to increase with an annual average growth of 5.9\% between 2012 and 2016 [42]. In 2018, Java-Bali consumed $74 \%$ of the total national electricity demand [43].

Table 1. Capacities of power generation, transmission, and distribution: total Indonesia and Java-Bali power system $[44,45]$.

\begin{tabular}{cccc}
\hline Assets & \multicolumn{3}{c}{ Capacity } \\
\hline & Indonesia & Java-Bali & $\begin{array}{c}\text { Percentage of the } \\
\text { Java-Bali Capacity }\end{array}$ \\
\hline Generation capacity (MW) & 59,656 & 38,690 & $65 \%$ \\
\hline Transmission network: & & & \\
Transmission lines (kmc) & 44,064 & 22,553 & $51 \%$ \\
Substation transformer (MVA) & 98,899 & 78,697 & $80 \%$ \\
\hline Distribution network: & & & $53 \%$ \\
Distribution lines (kmc) & 887,681 & 466,686 & $65 \%$ \\
Substation transformer (MVA) & 50,100 & 32,822 & \\
\hline Note: MW = megawatt; kmc $=$ kilometer circuit; MVA = megavolt ampere.
\end{tabular}


Being a vast archipelagic country with $81,000 \mathrm{~km}$ of coastline and 42 million inhabitants living in low-lying areas, Indonesia is highly vulnerable to the adverse impacts of climate change [46]. The rise in Indonesia's mean temperature is followed by more extreme events that trigger hydrometeorological hazards, including floods, landslides, and droughts [47]. With the increasing global warming, El Niño and La Niña also increase in frequency and intensity [48]. While previously El Niño generally occurred once in 2 to 7 years, since 1970, the frequency of El Niño and La Niña grew to once in 2 to 4 years [49]. Indonesia experienced a long dry season during El Niño in 1997 and 1998. Meanwhile, during La Niña in 1999, it experienced extreme precipitation with sea levels rise from $20 \mathrm{~cm}$ to $30 \mathrm{~cm}$. This mixture of incidents resulted in flooding in large regions of Indonesia, particularly along the coast [49]. Furthermore, in 2013, ten severe flood events affected 590,000 people, causing 3 billion USD of damages. Several severe floods also occurred in 2014 and 2015 [50]. Moreover, multiple sea transportation accidents were triggered by intense waves and ocean winds (e.g., the KM Senopati disaster on 29 December 2006 and the KM Teratai Prima disaster on 11 January 2008) [49].

Looking ahead, as many as 2000 small islands in Indonesia are projected to sink by mid-century. By 2100, an estimate of 5.9 million people every year will be affected by coastal flooding [46]. Other impacts of climate change include extended dry seasons, an increased frequency of extreme climate occurrences, and degraded biodiversity [47]. A World Bank analysis ranks Indonesia 12th among 35 countries with high mortality risks due to multiple hazards, including climate-related hazards such as floods, landslides, and droughts [51]. Accordingly, an estimated $40 \%$ of Indonesians are at risk of multiple hazards, including earthquakes, tsunamis, volcanic eruptions, floods, landslides, droughts, and forest fires [52]. Table A1 of Appendix A summarizes historical trends and projections of the Indonesian climate.

\section{Methodology}

To understand the actual effects of severe weather events and changes in climate variables on the Indonesian power sector, extensive fieldwork was carried out in February-March 2018. Our fieldwork focuses on the Java-Bali power system, covering the entire key segments of the power system: power generation, transmission, and distribution. The sources of the Indonesian electricity supply are primarily coal, natural gas, and hydropower. Hence, the investigated power generation plants comprised of major power plants of these types (Table 2). In total, our fieldwork covered power plants that constitute $35 \%$ of the total power generation capacity in the Java-Bali electricity grid (Source: own calculation based on [44,45]). Any disruptions that occur in these power plants, including weather and climate-related outages can cause power shortage throughout the whole Java-Bali power system. For the T\&D segments, we include the entire T\&D networks throughout the Java-Bali islands (Figure 1).

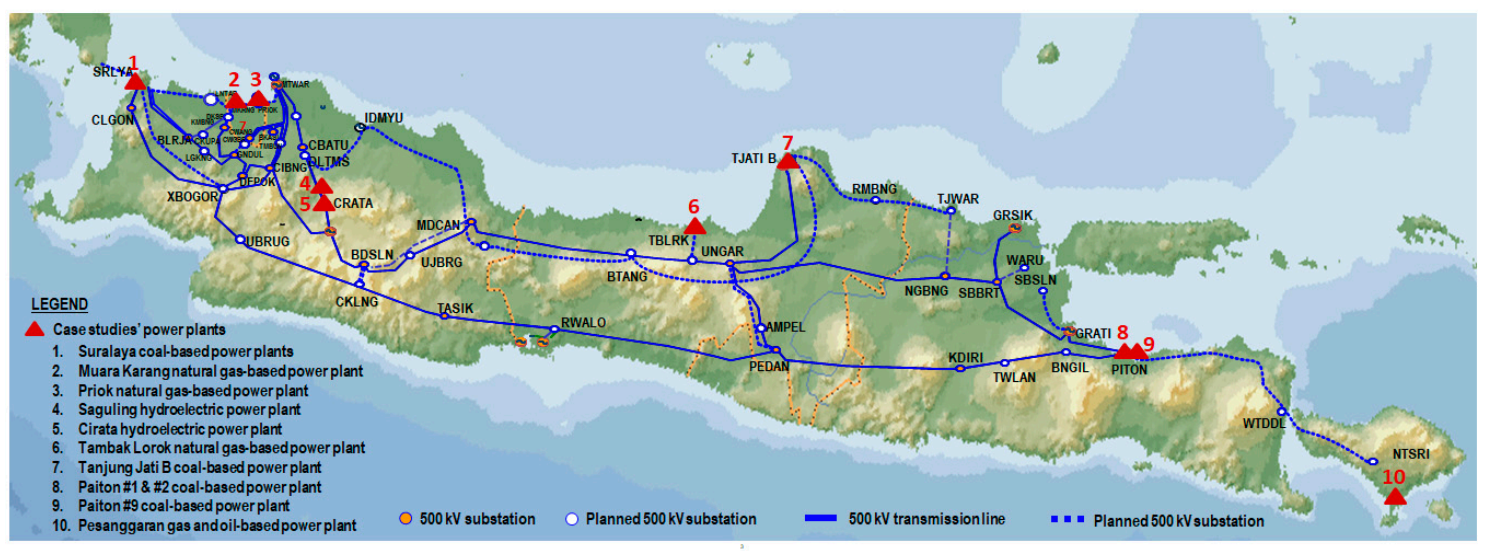

Figure 1. Power plants and extra-high-voltage Java-Bali transmission networks covered by this study, modified from [42]. While this figure depicts only the extra-high-voltage transmission networks, this study also includes high-voltage transmission networks and low-voltage distribution networks. 
Table 2. Indonesian power plants where primary data collection has taken place.

\begin{tabular}{cccccc}
\hline Power Plant & Utility & $\begin{array}{c}\text { Installed } \\
\text { Capacity (MW) }\end{array}$ & Location & $\begin{array}{c}\text { Primary } \\
\text { Energy Source }\end{array}$ & Data Collection \\
\hline Saguling & IP & 797 & West Java & Hydro & FGD \\
\hline Cirata & PJB & 1008 & West Java & Hydro & FGD \\
\hline Tanjung Priok & IP & 1900 & Jakarta & Natural gas & Interview \\
\hline Muara Karang & PJB & 909 & Jakarta & Natural gas & Interview \\
\hline Tambak Lorok & IP & 1350 & Central Java & Natural gas & Interview \\
\hline Pesanggaran & IP & 325 & Bali & Natural gas & FGD \\
\hline Suralaya & IP & 3400 & Banten & Coal & Interview \\
\hline Tanjung Jati B & PLN & 2640 & Central Java & Coal & Interview \\
\hline PJB Paiton & PJB & 800 & East Java & Coal & Interview \\
\hline Paiton \#9 & PLN & 660 & East Java & Coal & Interview \\
\hline
\end{tabular}

The fieldwork consisted of in-depth semi-structured interviews $(n=28)$ and five FGDs. The interviews involved key informants, holding various position levels (e.g., high and middle management levels, supervisory level, staff, and operators) of three electric utilities, who work across multiple business units (e.g., head office, load control center, transmission office, distribution office, and power plant). Meanwhile, the FGD was carried out at three power plants, one transmission office, and one distribution office. The respondents are employees of the utilities who are responsible for the operation and maintenance of power plants, transmission, and distribution infrastructures at different position levels. Prior to the fieldwork, we conducted a systematic review of studies that are concerned with the impacts of climate change on the power sector. After which, we drew six questionnaires (Table A2, Appendix B) for guiding interviews and FGDs, which were structured differently for each target group.

The interviews and FGDs were supplemented with reviews on secondary data, which consisted of utilities' internal reports and published energy information (Table 3). These data were used to validate and triangulate the results derived from the interviews and FGDs.

Table 3. Sources of secondary data.

\begin{tabular}{ccc}
\hline Data & Sources & Year Covered \\
\hline \multirow{2}{*}{ Disruptions in power plants } & P2B internal reports & 2011-2017 \\
& Media covers & 2007, 2008, 2011, 2013 \\
& Suralaya CFPP's internal report & 2011-2017 \\
\hline \multirow{2}{*}{ Disruptions in transmission lines } & P2B internal reports & $2011-2017$ \\
Disruption in distribution networks & Media cover & 2013 \\
\hline \multirow{2}{*}{ Precipitation, water inflow, and water spill } & PLN internal reports & $2014-2015$ \\
\hline The Java-Bali peak load & Cirata and Saguling HEPPs & Cirata: 1988-2017 \\
\hline Air temperature & internal reports & Saguling: 1986-2017 \\
\hline Average electricity tariff & P2B internal report & 2014 \\
\hline
\end{tabular}

Note: $\mathrm{CFPP}=$ coal-fired power plant; $\mathrm{HEPP}$ = hydroelectric power plant, $\mathrm{P} 2 \mathrm{~B}$ = the Java-Bali load control center (grid operator); BMKG = Indonesia's agency of meteorology, climatology, and geophysics. 
The findings of our fieldwork are summarized in a matrix that presents the identified impacts of weather and climate for each segment of the power system, including estimates of financial losses suffered by the utilities and their adaptation responses. We estimate financial losses using the energy-not-supplied (ENS) data associated with the weather-and climate-related disruptions in power plants, transmission lines, and distribution networks. The ENS data is multiplied by the average electricity tariff for a disruption event in the corresponding year. Meanwhile, there is only limited data available regarding the cost incurred by the utilities to repair the physical damages of their assets caused by severe weather events. Therefore, we report these costs per case, data permitting. There is hardly any data available regarding the probabilities of adverse events, which prohibits us from reporting the expected annual damages. Likewise, the data regarding costs associated with adaptation actions taken by the utilities is hardly available, due to proprietary data protection or lack of proper documentation.

\section{Results: Weather and Climate Effects and Adaptive Responses of the Power Sector}

The fieldwork reveals that weather and climate affect all segments of the power system: generation, transmission, and distribution. Tables 4-6 summarize findings regarding weather and climate impacts on power generation, transmission, and distribution segments of the power sector including financial losses suffered by the utilities and their responses to weather-and climate-related disruptions. Our findings reveal that adaptation so far occurs at the level of individual units within the electricity supply chain, mainly in response to the experienced weather-and climate-related disruptions. We observe no intentional, planned adaptation strategy focus on addressing climate change that was developed at the energy sector level beyond these decentralized adaptation actions. Therefore, within the context of the Java-Bali power system, the term adaptation refers to autonomous adaptation (IPCC defines autonomous adaptation as "adaptation in response to experienced climate and its effects, without planning explicitly or consciously focused on addressing climate change. Also referred to as spontaneous adaptation" [53]) of individual utilities.

The following section elaborates the impacts of severe weather events, which include heavy wind, heat waves, lightning, and heavy precipitation, which can lead to floods and landslides. Furthermore, Section 4.2 discusses the effects of gradual long-term changes in climate variables, which include rising ambient air and seawater temperatures, changes in precipitation patterns, and sea-level rise. 
Table 4. Impacts of severe weather events on power generation and utilities' autonomous adaptation measures. Source: own fieldwork.

\begin{tabular}{|c|c|c|c|c|c|c|}
\hline $\begin{array}{l}\text { Weather-and } \\
\text { Climate-Related Event }\end{array}$ & Impact Mechanism & Identified Impacts & Utility & Time Frame & $\begin{array}{l}\text { Estimated } \\
\text { UTILITIES' Losses } \\
\text { (in USD) }\end{array}$ & Adaptation Measures \\
\hline \multirow[t]{4}{*}{ Heavy precipitation } & $\begin{array}{l}\text { - } \quad \text { Dry coal were soaked } \\
\text { - Wet coals clogged coal feeders }\end{array}$ & $\begin{array}{ll}\text { - } & \text { Reduced } \\
& \text { burning efficiency } \\
\text { - } & \text { Reduced power output }\end{array}$ & Suralaya CFPP & 2011-2017 & 21.5 million & $\begin{array}{l}\text { - Construction of sheds to } \\
\text { protect the coal storage area } \\
\text { from rainwater }\end{array}$ \\
\hline & $\begin{array}{l}\text { - Increased river flow brought more } \\
\text { waste into the sea }\end{array}$ & $\begin{array}{l}\text { - Impeded power plants' } \\
\text { water uptake }\end{array}$ & $\begin{array}{l}\text { Muara Karang, } \\
\text { Priok, and Tambak } \\
\text { Lorok NGPPs }\end{array}$ & 2011-2017 & 15 million & $\begin{array}{l}\text { - Additional work hours for } \\
\text { waste cleaning } \\
\text { and transportation }\end{array}$ \\
\hline & $\begin{array}{l}\text { Days of heavy rainfall increased } \\
\text { water inflow to the hydropower } \\
\text { reservoir, causing the reservoir's } \\
\text { water spills }\end{array}$ & - $\quad$ Flooding downstream & & & N/A & $\begin{array}{l}\text { - Adjustment of hydropower } \\
\text { operation pattern to maintain a } \\
\text { normal reservoir's water level }\end{array}$ \\
\hline & $\begin{array}{l}\text { - Days of heavy rainfall } \\
\text { caused flooding }\end{array}$ & - $\quad$ Flooded power plant & $\begin{array}{l}\text { Muara Karang } \\
\text { NGPP }\end{array}$ & 2013 & 6.2 million & $\begin{array}{l}\text { - Construction of flood } \\
\text { control systems } \\
\text { Mobilization of portable water } \\
\text { pumps for draining the water } \\
\text { - Elevation of some areas of } \\
\text { power plants }\end{array}$ \\
\hline $\begin{array}{l}\text { Heavy wind and high } \\
\text { sea waves }\end{array}$ & Interruptions in coal shipping to CFPPs & $\begin{array}{l}\text { Reduced power } \\
\text { outputs/shutdowns }\end{array}$ & Suralaya CFPP & 2011-2017 & 1.2 million & $\begin{array}{l}\text { - Additional coal shipping fleets } \\
\text { - Changes in the type of fleets to } \\
\text { a stronger and bigger vessel }\end{array}$ \\
\hline Jellyfish inflow & $\begin{array}{l}\text { Jellyfish inflow into the cooling water } \\
\text { system of thermal power plants }\end{array}$ & $\begin{array}{l}\text { Reduced power } \\
\text { output/shutdown }\end{array}$ & Paiton \#9 CFPP & 2016 & 21.3 million & $\begin{array}{l}\text { - Installation of fishnets } \\
\text { - Cleaning of the water intake } \\
\text { area from jellyfish }\end{array}$ \\
\hline Heatwaves & Warm ambient air temperature & $\begin{array}{l}\text { Reduced efficiency of gas } \\
\text { turbine and gas/diesel engine } \\
\text { power plants }\end{array}$ & $\begin{array}{l}\text { Muara Karang } \\
\text { NGPP }\end{array}$ & 2016 & 4250 & $\begin{array}{l}\text { Installation of an inlet air cooling } \\
\text { system in gas turbine units to } \\
\text { maintain its performance during hot } \\
\text { ambient air temperatures }\end{array}$ \\
\hline
\end{tabular}


Table 4. Cont

\begin{tabular}{|c|c|c|c|c|c|c|}
\hline $\begin{array}{l}\text { Weather-and } \\
\text { Climate-Related Event }\end{array}$ & Impact Mechanism & Identified Impacts & Utility & Time Frame & $\begin{array}{c}\text { Estimated } \\
\text { UTILITIES' Losses } \\
\text { (in USD) }\end{array}$ & Adaptation Measures \\
\hline Drought & Critically low water inflow & Reduced power output & $\begin{array}{c}\text { Saguling and Cirata } \\
\text { HEPPs }\end{array}$ & 2011 & 51.5 million & $\begin{array}{ll}\text { - } & \text { Adjustments of monthly } \\
\text { operation pattern plans } \\
\text { - } & \text { Application of weather } \\
\text { modification technology }\end{array}$ \\
\hline Sea level rise & Tidal flooding & $\begin{array}{l}\text { Interrupted the daily activities } \\
\text { of the employees }\end{array}$ & $\begin{array}{l}\text { Tambak Lorok and } \\
\text { Priok NGPPs }\end{array}$ & $\begin{array}{c}\text { Occurs } \\
\text { periodically }\end{array}$ & N/A & $\begin{array}{l}\text { Elevation of some areas of power } \\
\text { plants }\end{array}$ \\
\hline Sea surface temperature & Warm seawater & $\begin{array}{l}\text { Reduced efficiency of the } \\
\text { cooling water system }\end{array}$ & PJB Paiton & & N/A & $\begin{array}{l}\text { Monitoring of seawater } \\
\text { temperatures }\end{array}$ \\
\hline
\end{tabular}

Table 5. Impacts of severe weather events on transmission networks and the utility's autonomous adaptation responses. Source: own fieldwork.

\begin{tabular}{|c|c|c|c|c|c|c|}
\hline $\begin{array}{c}\text { Weather-and } \\
\text { Climate-Related Event }\end{array}$ & Impact Mechanism & Identified Impacts & Utility & Time Frame & $\begin{array}{l}\text { Estimated Utility's } \\
\text { Losses (in USD) }\end{array}$ & Autonomous Adaptation Measures \\
\hline Lightning & $\begin{array}{l}\text { Lightning strike induced overvoltage } \\
\text { and flashover }\end{array}$ & $\begin{array}{l}\text { Power failures and transmission } \\
\text { equipment damages }\end{array}$ & PLN & 2011-2017 & 524,091 & $\begin{array}{l}\text { - Installation of the lightning } \\
\text { monitoring system } \\
\text { - Improvement of the lightning } \\
\text { protection system }\end{array}$ \\
\hline Heavy wind & $\begin{array}{l}\text { Objects being blown onto the } \\
\text { conductors or heavy wind detaching } \\
\text { the conductors from the isolator }\end{array}$ & $\begin{array}{l}\text { Power failures and transmission } \\
\text { equipment damages }\end{array}$ & PLN & 2011-2017 & 22,139 & Repair the damaged equipment \\
\hline Flood & Flooded substations & $\begin{array}{l}\text { - Inundated substations were } \\
\text { deliberately turned off for } \\
\text { safety reasons } \\
\text { - } \quad \text { Damaged equipment }\end{array}$ & $\begin{array}{l}\text { PLN (transmission } \\
\text { assets in Jakarta) }\end{array}$ & 2013 & 9.1 million & Elevate the flood-prone substations \\
\hline
\end{tabular}


Table 6. Impacts of severe weather events on distribution networks and the utility's autonomous adaptation responses. Source: own fieldwork.

\begin{tabular}{|c|c|c|c|c|c|c|}
\hline $\begin{array}{l}\text { Weather-and } \\
\text { Climate-Related Event }\end{array}$ & Impact Mechanism & Identified Impacts & Utility & Time Frame & $\begin{array}{l}\text { Estimated utility's Losses } \\
\text { (in USD) and the Number } \\
\text { of Affected Customers }\end{array}$ & Adaptation Responses \\
\hline Heavy wind & $\begin{array}{l}\text { Uplifted objects damage } \\
\text { bare conductors }\end{array}$ & Power outages & PLN & 2014-2015 & $\begin{array}{l}13.1 \text { million } \\
2.1 \text { million customers } \\
\text { were affected }\end{array}$ & $\begin{array}{l}\text { - } \quad \text { Conduct routine inspections } \\
\text { - } \quad \text { Alert the 24-hour technical service teams } \\
\text { avply segmentation of protection systems to } \\
\text { avidespread power outages }\end{array}$ \\
\hline Heavy precipitation & $\begin{array}{l}\text { Wet and heavy branches touch } \\
\text { the bare conductors }\end{array}$ & Power outages & PLN & 2014-2015 & $\begin{array}{l}575,152 \\
3.1 \text { million customers } \\
\text { were affected }\end{array}$ & $\begin{array}{l}\text { - Check and maintain distribution networks } \\
\text { (e.g., clear distribution lines from tree } \\
\text { branches) before the wet season come } \\
\text { - Alert the 24-hour technical service teams }\end{array}$ \\
\hline Flood & $\begin{array}{l}\text { Inundated substations were } \\
\text { deliberately turned off for } \\
\text { safety reasons }\end{array}$ & Power outages & PLN & 2014-2015 & $\begin{array}{c}455,605 \\
92,528 \text { customers } \\
\text { were affected }\end{array}$ & $\begin{array}{l}\text { - Identify and elevate flood-prone substations } \\
\text { - } \quad \text { Replace old underground conductors that } \\
\text { - } \quad \text { Establish a computer application to monitor } \\
\text { the area affected by flood-induced } \\
\text { power outages } \\
\text { - Establish a disaster recovery center and a } \\
\text { special service team for post-flood recovery }\end{array}$ \\
\hline Landslide & $\begin{array}{l}\text { Heavy precipitation and heavy } \\
\text { winds triggered landslides, } \\
\text { causing distribution } \\
\text { networks damages }\end{array}$ & Power outages & PLN & 2014-2015 & $\begin{array}{c}9234 \\
328,775 \text { customers } \\
\text { were affected }\end{array}$ & $\begin{array}{l}\text { - Identify landslide-prone poles } \\
\text { - Improve poles' foundation }\end{array}$ \\
\hline
\end{tabular}




\subsection{Impacts of Severe Weather Events}

\subsubsection{Disruptions Due to Heavy Precipitation}

- $\quad$ Flood and landslide affect electricity supply infrastructure

Heavy precipitation increases the chances of flooding in low-lying delta areas, making coastal thermal power plants and transmission substations vulnerable to flooding. According to the interviews and reviews on various documents, flooding generally results in acute situations. A notable example is a severe flood that occurred on the Northern coast of Jakarta in January 2013 that forced a 909-megawatt natural gas power plant to shut down for 12 days. Moreover, at least 546 units of an inundated distribution substation were turned off. These instances led to an estimated loss of 15.3 million USD suffered by electric utilities due to the disruptions of electricity production that month and physical damages of the power plant, transmission, and distribution equipment. The societal loss could be much more significant considering the vital function of the power plant and its associated transmission and distribution networks as the backbone of the electricity supply to the capital city. Assessing these indirect effects are out of the scope of this fieldwork and require modeling efforts. Besides the severe flood in 2013, PLN documentation also reveals flooding events for the years 2014 and 2015. There were 354 and 19 floods recorded, respectively, which affected the Java-Bali distribution networks. During the flooding, PLN deliberately turned off the inundated distribution substations and lines for safety reason. The ENS due to these events reached 6.3 gigawatt-hours with an estimated loss of nearly 0.5 million USD suffered by the utility over two years. These events affected 89,102 customers with an average of 16-outage-hours and 1.7-outage-hours for each affected customer in 2014 and 2015, respectively.

- Heavy precipitation often causes failures in distribution networks

Respondents of distribution offices and reviews on PLN reports indicate heavy precipitation as the second primary cause of weather-related outages in distribution networks. By the end of 2015, the length of distribution lines throughout the Java-Bali islands was a 22,553-kilometer circuit [45]. These lines pass through many trees, which include community, agricultural, and forest trees. Since the majority of these lines consist of bare overhead conductors, they are sensitive to contact with tree branches or other objects. During heavy precipitation, wet tree branches along the distribution line become heavier and often touch the lines' bare conductors causing short circuits and triggering the protection system to cut off the power. Moreover, if heavy precipitation is accompanied by severe lightning, PLN deliberately cuts the power supply off to avoid the channeling of lightning current to houses through the distribution networks' conductors.

Between 2014 and 2015, heavy precipitation caused 1048 events of power outages in the Java-Bali distribution network. These events result in 8.3 gigawatt-hour ENS that is equal to an estimated loss of more than 0.5 million USD over the two years. The total amount of customers impacted exceeds 3.1 million; each underwent an annual average of 0.99-outage-hour due to heavy-precipitation-related failures in distribution networks. The FGD confirms that the utility is well aware of the risks posed by heavy precipitations. Therefore, preventive measures have been taken to minimize the risks (Table 6).

\section{- Heavy precipitation reduces coal quality}

Coal-fired power plants (CFPPs) generally store coals in open areas (coal yards). As heavy rainfall soaks the dry coal, the plants' burning efficiency reduces. Moreover, rainwaters generate excessive coal runoff, which in severe cases, inundates coal yards. Respondents highlight that; subsequently, the coals turn into sticky sludge, causing clogging in the coal feeder, which prevents a continuous, reliable coal supply to plants' burning chambers and reduces power output. For example, document reviews reveal that the Suralaya CFPP has experienced 544 occurrences of a power output reduction due to a clogged coal feeder during 2011-2017. Consequently, the total ENS over the seven years for this power plant alone reached 277.6 gigawatt-hours, resulting in estimated losses of 21.5 million USD. 
The power plant reacted by building a shed in its coal yard, which currently accommodates around $10 \%$ of the coal storage area.

- Heavy precipitation brings waste to power plants' water intake area

Heavy precipitation increases river flows, which in turn bring more waste into the sea. An increased volume of waste in the sea creates problems for coastal power plants. The respondents of coal- and natural-gas-based power plants stress that small-size waste escapes water intake filter and enters the cooling water system, causing clogging in the water-circulating pump and plugging in the condenser. Interviews and companies' documentations point to the fact that waste has forced some units of natural gas-based plants to shut down temporarily in severe cases.

The fieldwork finds that increased waste driven by heavy rainfall affected the three natural gas power plants (NGPPs) of the case studies: Muara Karang, Tambak Lorok, and Priok. A high-quantity of waste on water intake areas have caused reductions in their power outputs. In total, the ENS due to interruptions in these three power plants nearly reached 190 gigawatt-hours causing an estimated loss of 15 million USD during 2011-2017. Furthermore, the Muara Karang NGPP recorded eight events of waste-related forced shutdowns over the considered seven-year period.

The massive amount of waste requires a significant number of workforce. For instance, at Muara Karang NGPP alone, the waste cleaning in its two water intake areas involves at least 80 personnel who work in shifts for $24 \mathrm{~h}$ in two water intakes. The collected waste is transported outside the plant twice a week. However, during the peak amount of waste, daily transportation is needed, as respondents reported.

\subsubsection{Disruptions Due to Heavy Wind}

- Heavy wind damages electricity supply infrastructure

Heavy wind is by far the greatest threat for the Java-Bali distribution networks (Table 6). For example, during 2014-2015, it was responsible for $95 \%$ of the weather-related power outages. The interviews with representatives of distribution offices indicate that heavy wind can knock down trees and billboards and throw them and other objects onto the bare conductors of the distribution networks, thereby causing power outages. Multiple occurrences of heavy wind over the two years resulted in 275 gigawatt-hours of ENS, leading to an estimated loss of 13.1 million USD for PLN over the two years. The total number of affected customers exceeds 2.1 million over the two years; each encountered an annual average of 1.02-outage-hours due to heavy-wind-related failures in the distribution networks.

Meanwhile, in the transmission networks, there were only 12 heavy-wind-related power outages recorded from 2011 through to 2017, owing to their stronger tower structure and higher conductors as compared to distribution networks. These events resulted in 0.28 gigawatt-hours of ENS, which equals to 22,139 USD of financial losses over the seven years (Table 5). Respondents identify three reasons for the heavy-wind-related outages in T\&D networks: (i) heavy wind blew tree branches or other objects onto the conductors; (ii) heavy wind caused the conductors to swing and hit the pole/tower's body; (iii) Heavy wind detached the conductors from the insulators.

Respondents of the distribution offices state some proactive measures they have taken responding to heavy-wind-related disruptions. They monitor weather forecasts; in case a heavy wind is approaching, they alert its 24-hours technical service teams and ensures sufficient people and materials available to overcome any damage that may occur when the heavy wind comes. Beside corrective measures, PLN also includes preventive measures by conducting inspections on its distribution networks. The inspection includes cutting tree branches that could potentially harm the distribution network when heavy wind occurs. The inspection also checks and maintains pole stands to ensure that they are supported by an adequate foundation. In case a power outage occurs due to severe weather, PLN prevents widespread power outages by applying segmentation of the distribution's protection 
system. Meanwhile, the response of transmission offices to heavy-wind-related disruptions so far has been on the investigation of the cause of power transmission failures and repairing the damaged equipment without any ex-ante adaptation actions.

Heavy winds also cause damages to power plants' facilities. For example, in 2007, a heavy wind slammed two coal ships, causing them to crash into the coal loading facility of the Tanjung Jati B CFPP. Consequently, the coal unloading facility did not function for two weeks, which resulted in a critical stock of fuel coal in the power plant, forcing the plant to shut down for some time. Furthermore, in March 2017, a heavy wind lifted the roof of the coal yard's dome of Paiton \#9 CFPP and crooked some of the dome pipes. Nothing has been done in terms of improving the resiliency of infrastructure against the severe weather.

- Heavy wind disrupts the fuel-coal stock

The interviews with representatives of head office and CFPPs reveal that heavy wind and high waves in the Java Sea affect coal transportation to Java Island. The CFPPs sited in Java rely on sea-shipped coals from coalmines of other islands. During heavy winds, coal loading and unloading activities are prohibited, which causes a longer waiting time for coal deliveries. Moreover, high waves in the Java Sea, which often occur during the wet season, prevent coal barges from cruising. These circumstances jeopardize the stock of coal at CFPPs, which often lead to reductions in the plants' power outputs. For instance, in 2007, Tanjung Jati B CFPP experienced critical fuel coal stocks twice-in March and December-due to severe weather in the Java Sea. The media reported forced shutdowns of the CFPP for days due to the disruptions in coal supply [54,55]. Consequently, the costly oil-fueled power plants were operated to substitute such capacity loss in the Java-Bali grid, causing an additional cost of 1.6 million USD per day during those critical days in March and December 2007 [56].

Recent data from the fieldwork show that severe weather events in the Java Sea continue posing threats to the security of coal supply for CFPPs. In December 2017, the average coal stock of Tanjung Jati B was only enough for 13 days of operation, which was halved of the planned stock of 25 days. By the end of January 2018, the stock was only enough for three days of operation, leaving the plant vulnerable to a forced shutdown. Similarly, the average coal stock of PJB Paiton CFPP in January 2017 reached a critical point, i.e., less than three days. In Suralaya CFPP, the disturbances in coal stock between 2011 and 2017 resulted in an estimated loss of 1.2 million USD in total. As per our interviews, to avoid critical fuel coal stocks during severe weather events, CFPPs responded by revising their contracts to add the number of coal shipments and to use stronger and larger vessels.

\subsubsection{Heatwave Effects on Electricity Supply and Demand}

- Heatwave reduces generation capacity of natural gas power plants

The heatwave is particularly a concern for natural gas power plants. Interviews with representatives of NGPPs indicate that warm air temperatures affect the gas turbines and gas engines of NGPPs. The operation of this type of power plants requires ambient air for compressor intake, which is then pumped into the burning chamber. The higher the air ambient temperature, the lower the air density and, hence, the burning efficiency, which then reduces power outputs.

Utilities recorded disruptions in several NGPPs attributable to heatwaves. On 17 March 2015, two units of gas turbines in the Muara Karang NGPP reduced their power outputs by $14 \%$ and $17 \%$ each due to the hot temperature outside, which was measured at $35^{\circ} \mathrm{C}$. Similarly, on 3 May 2016, two other units of the same power plant experienced a reduction in power output by $3 \%$ of their capacity due to high ambient air temperature. The latter caused an estimated loss of 4250 USD suffered by the power plant on that particular month alone. Another case that is worth mentioning is a disruption that occurred in the Pesanggaran NGPP. During our visit on 1 March 2018, the ambient temperature was $33^{\circ} \mathrm{C}$. At this temperature, the engine could not deliver the optimum power output. The screen in the control room shows "automatic derating" notification with an explanation of the cause: a high 
ambient air temperature. The notification means that the engine automatically reduces its output due to high air temperature.

The FGD and interviews reveal that reductions in power outputs due to high ambient temperature have not been a substantial issue for the Java-Bali electricity grid as a whole. However, for the Bali subsystem, it was a significant problem in 2010 due to its limited power generation capacity while the power transfer from the Java subsystem was also constrained by a technical barrier in the transmission networks. Hence, it was essential to optimize power output from local plants in Bali. Therefore, the Pesanggaran NGPP in Bali adapted by installing an inlet air cooling system in its gas turbine units to maintain the machine performance during hot temperatures.

- Heatwave increases electricity use

Respondents confirm an increase in electricity demand during hot temperatures days. Similarly, our review on utilities' internal documents reveals that in the Bali subsystem alone, the difference in peak demand between hot and cold days/nights can reach $100 \mathrm{MW}$-around $12 \%$ of the peak demand in 2017. Hence, a surge in electricity demand due to warmer temperature directly affects the power system, as the system should be able to accommodate any surge in electricity demand. In the long-term, an increased mean temperature will require a more substantial investment in power generation, transmission, and distribution networks to cope with the increased energy use (MWh) and higher peak demand (MW) [16].

\subsubsection{Disruptions Due to Lightning Strikes}

Respondents from the transmission offices point to lightning strike as the leading cause of weather-related disruptions in high-voltage transmission lines. According to the interviews, a lightning strike can induce an overvoltage on transmission lines and cause a flashover, which results in power failures, and damages power transmission equipment. Therefore, transmission lines generally equipped with shield wire and insulation to protect them from a lightning strike (Table 5). However, lightning strikes that occur too frequently can reduce the lifetime of the protective equipment, causing an increase in transmission's failure and its maintenance costs. The fieldwork reveals 107 events of lightning strike-related power outages in transmission networks throughout the Java-Bali power system during 2011-2017. The total ENS during the same period was 67 gigawatt-hour, which is equal to 0.52 million USD over the seven years.

Being aware of the risks posed by lightning, PLN established a lightning monitoring system, which derives the data regarding the occurrence of lightning strikes in the transmission network areas. The monitoring system produces a lightning density map and data regarding the exposure of lightning to the transmission network. The transmission offices compare these data with the disruption events in the transmission networks to conclude whether a disruption occurred due to lightning or something else. In case lightning strikes are found responsible for any disruptions in a specific transmission line or substation, PLN improves the lightning protection facilities at this location. Such improvements include installation of transmission line arresters and improvement of grounding systems and earth wire conductor materials. PLN also use the lightning data as a consideration for the planning of transmission network's development.

\subsubsection{Disruptions Due to Jellyfish Inflows}

We add 'jellyfish outbreak' into the extreme category because, in this context, it is associated with a drastic seawater temperature change [57]. Jellyfish inflow on thermal power plants is an extreme event that occasionally occurs on the northern coast of Java. According to interviews, jellyfish often escape the screening facilities of water intake, causing a problem in the cooling water system of CFPPs. A severe jellyfish inflow can cause a reduction in power generation capacity or even force the power plant to shut down. For example, in April 2016, the jellyfish inflow in Paiton \#9 CFPP forced the plant to shut down for 20 days, causing an estimated loss of 21.7 million USD. According to the 
Indonesian agency of meteorology, climatology, and geophysics, the jellyfish outbreak was triggered by an extremely cold temperature in the Australian sea, forcing jellyfish to migrate to the North Java Sea [57].

The first emergency response to the jellyfish inflow at that time was cleaning and spraying the traveling screen, cleaning the inlet of water intake, and installing fishnet on the water intake canal. However, these responses were not enough to block the jellyfish inflow, and at the end, the plant was forced to shut down. After the plant was shut down, manual cleaning of the water intake canal was carried out, involving 90 personnel, including divers. The damaged equipment was also repaired. The shutdown of Paiton \#9 CFPP caused a power supply shortage in the Java subsystem. Consequently, the Java subsystem had to import the expensive oil-based electricity from the Bali subsystem.

Jellyfish inflow also occurred in the water intake area of Tanjung Jati B CFPP. The jellyfish inflow blocked the water uptake of the cooling water system, which eventually caused reductions in power output. From 2011-2017, there were 11 occurrences of jellyfish inflow that affected the Tanjung Jati B electricity productions. The problem was generally solved within $0.5 \mathrm{~h}$ to a few hours. The estimated loss suffered by Tanjung Jati B due to the jellyfish-induced reductions in the plant's energy production reaches 0.3 million USD over the seven years. Apart from the jellyfish migration from the Australian sea, the jellyfish outbreak can be attributed to a warmer sea temperature $[58,59]$. So far, the power plant has taken ex-post measures such as installing fishnets and cleaning the water intake area from the jellyfish.

\subsection{Impacts of Gradual Changes in Climate Variables}

\subsubsection{Changes in Precipitation Pattern Affect Hydroelectric Power Plants}

The FGDs with representatives of two hydroelectric power plants (HEPPs) conclude that changes in precipitation patterns already affect the hydropower operation today, raising concerns about future climate conditions. Our analysis based on the HEPPs' data confirms the strong correlation between precipitation, water inflow to the reservoir, and electricity production of hydropower (Figures A1 and A2, Appendix C). The primary climate-induced challenge for hydropower is, therefore, to manage the situation during extreme wet and dry seasons. While in normal years, electricity production reaches $100 \%$, or slightly above the design capacity, in dry years, electricity production reduces significantly. For example, reductions in generated capacity due to long-lasting drought were observed in 1997, 2003, 2006, and 2011. In 2011 alone, both Saguling and Cirata HEPPs only utilized $87 \%$ and $75 \%$ of their design capacities, respectively, resulted in 51.5 million of financial losses. Furthermore, in September 2011, they were only able to operate half of their capacity and only to serve the peak demand [60]. Table 7 compares the energy generated in extremely dry years with their design capacities and estimates the ENS due to the lack of water.

Table 7. Percentage of electricity production in dry years compared to design capacities. Source: own analysis.

\begin{tabular}{|c|c|c|c|}
\hline \multirow{2}{*}{ Dry Years } & \multicolumn{2}{|c|}{ Percentage of Energy Generated Compared to Design Capacity } & \multirow{2}{*}{$\begin{array}{l}\text { Total ENS for Both } \\
\text { HEPPs (GWh) }\end{array}$} \\
\hline & Saguling & Cirata & \\
\hline 1997 & $61 \%$ & $60 \%$ & 1400 \\
\hline 2003 & $81 \%$ & $67 \%$ & 882 \\
\hline 2006 & $70 \%$ & $62 \%$ & 1174 \\
\hline 2011 & $87 \%$ & $75 \%$ & 637 \\
\hline
\end{tabular}

In contrast, days with heavy rainfalls result in high water levels of the reservoirs. This situation gives a positive impact enabling the HEPPs to produce electricity at their maximum capacity. However, excessive water inflow can lead to water spills, which should be avoided as much as possible as it can increase the downstream flow and cause flooding. For example, heavy precipitations along the 
Citarum watershed in March-April 2010 led to a significant inflow to the two reservoirs and also to another reservoir of the same watershed, causing lasting downstream flooding [10]. Figure 2 presents historical water levels and energy spills of the Saguling reservoir, indicating that peaked water inflows are followed by water spills, which calculated as energy spills. While the frequency of energy spills decreased in the last ten years compared to the first ten years of the Saguling HEPP operation, there was an increase in intensity. In 2016, the amount of energy spill reached the highest record over 29 years of the HEPP operation.

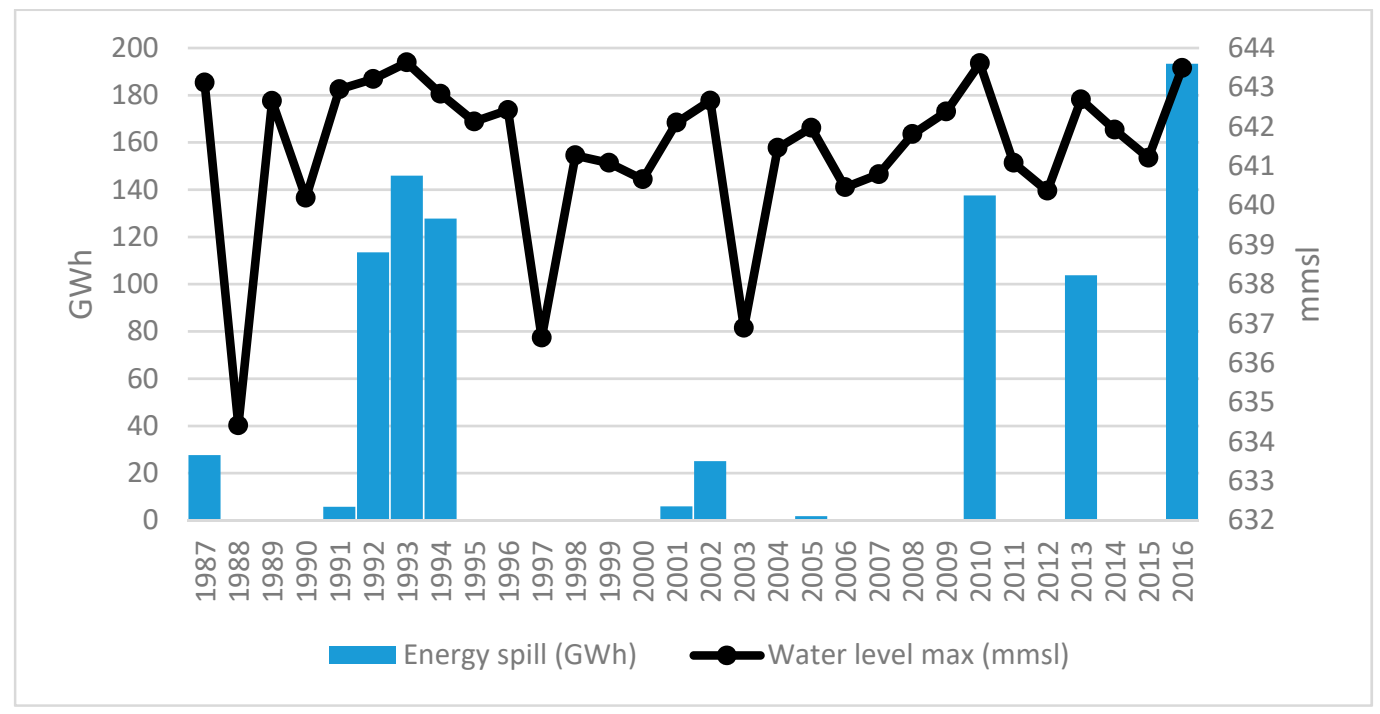

Figure 2. Annual maximum water levels and energy spills: Saguling HEPP from 1987 through to 2016. Source: own fieldwork.

Both HEPPs take managerial and technological adaptation responses to address low water inflows. The former is done through an adjustment of the HEPPs' operation pattern plans. While in the normal situation Cirata and Saguling HEPPs can be called to supply electricity at any time to meet demand and to stabilize the power system, during low water levels in reservoirs, they are only operated to serve the increasing energy demand during the peak hours [60]. The technological response is through an application of weather modification technology that creates artificial rain, which was done in 2011 when extreme drought occurred. Meanwhile, when there is excessive water enter the reservoirs, the HEPPs should maintain the standard reservoir's water level by maximizing water use for producing electricity. However, in severe cases, water spill could not be avoided.

\subsubsection{Warmer Ambient Air Temperature Increases Electricity Use}

The mean annual temperature in Indonesia has increased by $0.04{ }^{\circ} \mathrm{C}$ per decade between 1985 and 2015 [50]. As discussed in Section 4.1.3, the interviews indicate a rise in electricity demand during warmer temperatures. To validate this, we use the hourly load data, and the peak electricity demand data collected from the Java-Bali load control center (P2B) and relate these data to the average temperature data from 23 weather stations retrieved from BMKG [61]. We find a strong relationship between an increase in electricity use and air temperature increases (Figure 3). Therefore, an increase in the mean temperature is expected to boost the average electricity consumption. 


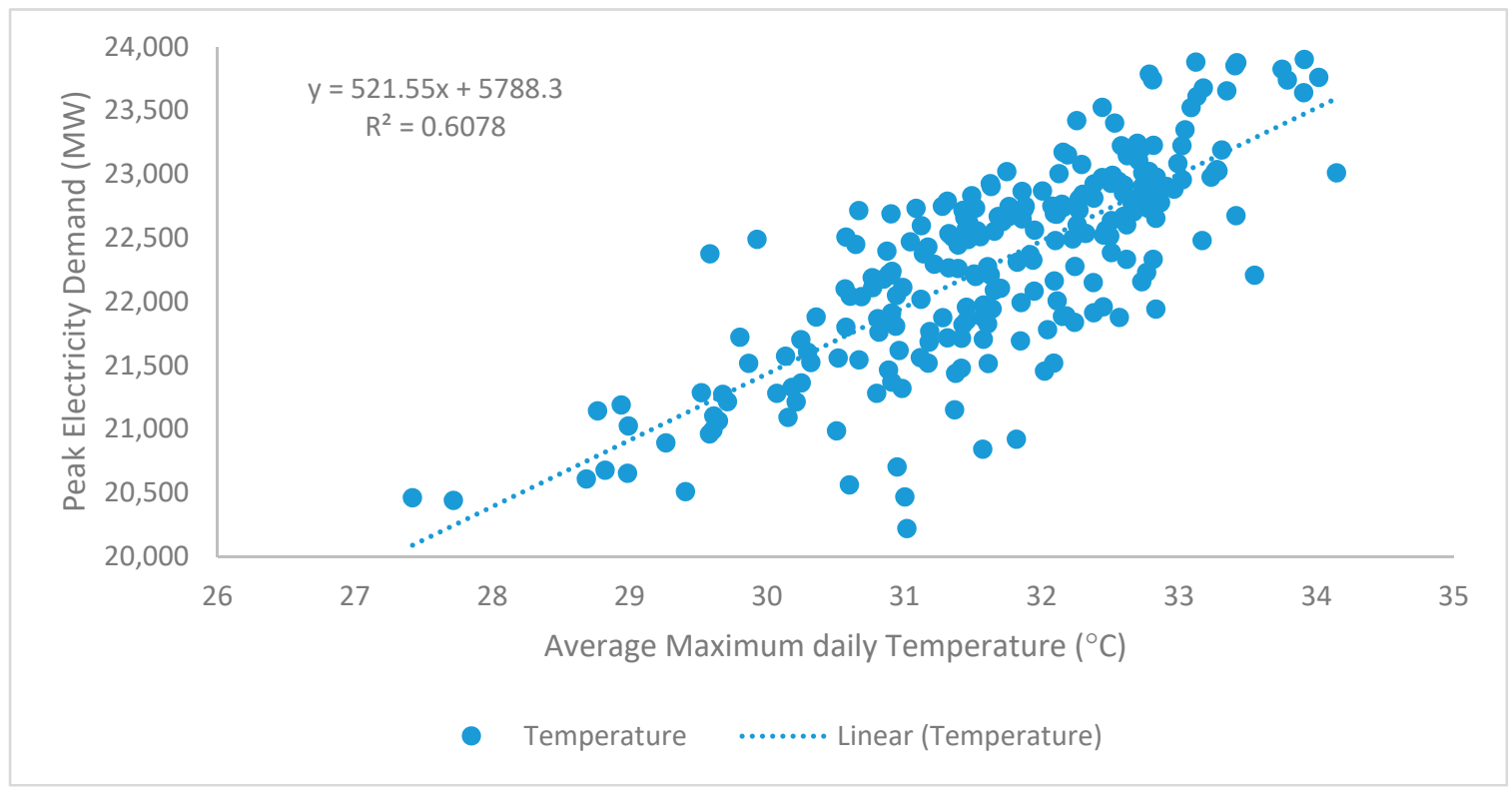

Figure 3. Peak electricity demand in the Java-Bali grid as a function of maximum daily temperature: weekdays 2014 (240 data points). Source: own fieldwork.

\subsubsection{Seawater Temperature Affects the Cooling Water System}

The seawater temperature is crucial for coastal power plants, which rely on seawater for their cooling systems. The temperature of the cooling water correlates with the performances of a condenser of a cooling water system. Respondents of the PJB Paiton CFPP revealed that higher temperatures resulted in higher pressures of the condenser, which, in turn, reduced the efficiency of the power plant. Based on this information, we examine the relationship between the cooling water temperature and the performance of a condenser, based on the condenser monitoring data provided by PJB Paiton. The result shows a strong correlation between the cooling water temperature with the condenser pressure (Figure 4). Although PJB Paiton monitors the seawater temperature data and evaluates its impact on the power plant's performance, no concrete capital or technological adaptation response has been taken.

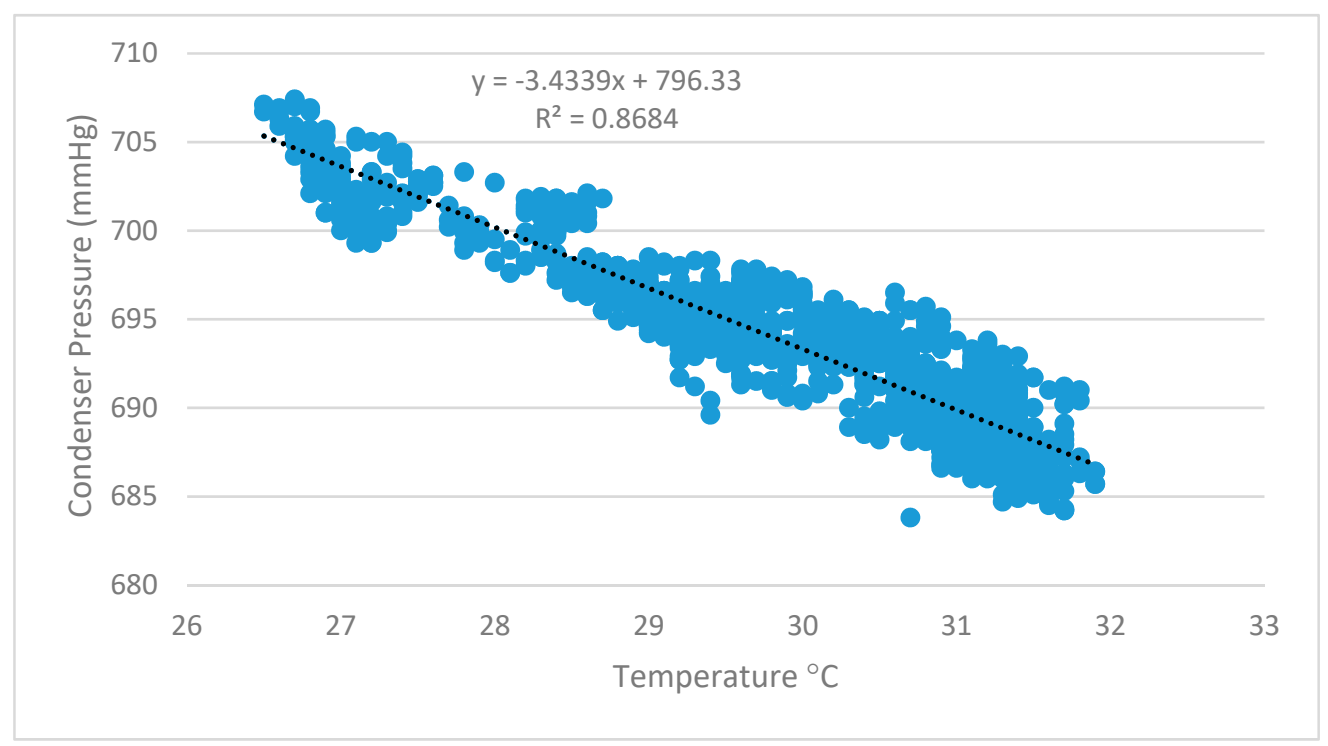

Figure 4. The condenser vacuum as a function of cooling water temperature: PJB Paiton CFPP, half-hourly, December 2015 (1409 data points). Source: own fieldwork. 


\subsubsection{Sea-Level Rise Contributes to Tidal Flooding}

Indonesia has recorded 2 to $10 \mathrm{~mm}$ of annual sea-level rise from 1993 to 2012 [46]. Sea-level rise threatens coastal power plants and their associated transmission substations. Tidal flooding often occurs in coastal power plants, especially during high tide and heavy precipitation. For example, Priok and Tambak Lorok NGPPs are often hit by tidal flooding. Priok NGPP, which is located on the Northern coast of Jakarta, lies in the altitude of $0-2 \mathrm{~m}$ above sea level. It is a flood-prone area where nine rivers and two flood canals meet. The lower parts of the power plant have often inundated, disturbing some activities such as employees' mobility between buildings. The water inundation level is considered dangerous when it reaches $35 \mathrm{~cm}$, which has occurred in 2007 and 2008. Respondents point out that tidal flooding has never caused production failure so far because the powerhouse is located on the higher altitude of the power plant area. However, in 2007, one of the Priok NGPP's transformers was flooded. Hence, it was deliberately disconnected from the grid during the flooding for safety reasons. During the 2007 and 2008 flooding, the Priok NGPP mobilized a portable water pump for draining the water. After the floods, some area of the plants were also elevated.

Tambak Lorok NGPP is located on the Northern Coast of Semarang, Central Java at the elevation of $0.75-1.5 \mathrm{~m}$ above sea level [62]. The sea-level rise in combination with land subsidence makes the plant vulnerable to tidal flooding and future changes in these due to climate change. The flooding occurs periodically; in fact, when the field visit was conducted in February 2018, the front gate of the plant was flooded. As an adaptation to this situation, the Tambak Lorok NGPP constructed a flood control system, which included a polder, water sump pumps, a wall, and upgraded its drainage system to improve its resilience (building upon the IPCC definition of resilience [33], we define resilience as the ability of a power generation/transmission/distribution system and its components to anticipate, absorb, accommodate, or recover from the effects of a hazardous event in a timely and efficient manner, potentially through ensuring the preservation, restoration, or improvement of its essential basic structures and functions) against seawater surge. Moreover, an additional polder is currently under construction to manage water inflow from the front side of the plant.

\section{Conclusions and Policy Implications}

This paper aims to systematically investigate the effects of severe weather events and changes in climate variables on the electricity supply chain, taking Indonesia as an example of a developing country where natural hazards already undermine the resilience of the power sector today. Relying on extensive fieldwork carried out in 2018, this paper reveals which, and how severe weather events and changes in climate variables adversely impact the Indonesian power sector. We run semi-structured interviews and FGDs with representatives of different segments of the electricity supply chain and review internal utility reports and published energy sector information. These data reveal the main mechanisms that cause adverse impacts to the power sector, including past losses both in energy-not-supplied and in USD and indicate the adaptation options already taken by the actors in the Indonesian power sector.

Severe weather events and gradual changes in climate variables affect all segments of the power sector, namely generation, transmission, and distribution. Our findings suggest that, in terms of the frequency of failures, the distribution network segment is the most vulnerable to severe weather events. Meanwhile, weather-related disruptions occur less frequently in the power generation segment. Nevertheless, whenever it does happen, the magnitude is significant, knocking out power plants for days and causing tens of millions of USD in the direct damage alone. Furthermore, severe weather mainly affects the fuel-coal quality and availability for coal-fired power plants, and the cooling water system in both coal- and gas-based power plants. This raises concerns regarding climate-resilience of fossil-fuel-based electricity production, which to date outprices green electricity options in Indonesia and forms the core of its future electrification plans. Changes in precipitation patterns also affect hydropower operation, undermining its role for serving electricity demand during peak hours. Concerning the transmission network, the primary cause of weather-related disruptions is 
the lightning strike. Yet, the weather-related damage in this segment is minor when compared to those in the distribution and generation segments.

To some extent, actors throughout Indonesia's electricity supply chain already implement adaptation actions in response to severe weather events, combining managerial and technological interventions. The technological responses include investments in flood control systems in power plants, a lightning monitoring system for the transmission networks and an application of weather modification technology to create artificial rain to increase water inflow to hydropower reservoirs. Managerial responses include altering coal shipment contracts, increasing routine distribution network checks, and altering hydropower operation patterns. However, these adaptation responses are limited to ex-post reactions to weather- and climate-related disruptions encountered by utilities. Furthermore, the responses are fragmented rather than a part of a national strategy and focus only on assets already adversely affected. Meanwhile, a long-term strategic plan that ex-ante anticipates future climate change-related risks and systematic adaptation responses have not been considered.

Several policy implications for the Indonesian electricity sector could be drawn from this analysis. These are likely to be shared by other developing countries, which typically have vulnerable electricity infrastructure $[11,31]$. Firstly, our results show that severe weather events and changes in climate variables have caused widespread power cuts, resulting in tremendous financial losses for utilities. However, the vulnerability analysis of Indonesia's electricity sector to climate change is still lacking nationally. Given the sector's vital role in meeting the electrification and climate change mitigation goals, the country must improve the sector's resilience to climate change. The first step towards a low-carbon, climate-resilient electricity sector would be to acknowledge the vulnerability of the sector to climate change and integrate the sector's climate change adaptation plans into the national action plans for climate change adaptation. The critical question here is to determine whether it is enough to scale up the existing adaptation responses or if a transformational adaptation is required to assure a climate-resilient development path. Co-benefits and synergies between climate mitigation goals-the massive introduction of renewables into the current fossil fuel dominated energy mix - and climate adaptation efforts should be explored to increase the climate resilience of the sector.

Secondly, our analysis shows that the sector's adaptation to climate change has been reactive following weather- and climate-related damages and losses. Ex-post adaptation focused on the extent and probability of past adverse events faces limitations in the climate-changed world. Increasing severity and likelihood of hazard events in a future climate calls for ex-ante strategies, especially when an expansion of the electricity system is considered. The future sector's resilience is co-developed today, requesting the integration of climate change projections, the assessment of physical and economic impacts, and possible incremental or transformational adaptation responses [63] into the sector's long-term development plan.

Finally, considering the adverse impact of climate change on the electricity sector, it is crucial for the electric utilities to include climate change adaptation into their long-term business strategies and capacity building. Increasing awareness of the electricity sector's stakeholders regarding climate change consequences for the sustainability of their business operations is an essential milestone.

This paper contributes to the literature by providing empirical insights into the actual effects of severe weather events and changes in climate variables on the entire electricity supply chain in developing countries, both in physical and monetary terms where data permitted. Moreover, this paper provides unique information on the variety of the actual adaptation responses of actors throughout different segments of the electricity supply chain to severe weather events. Future research might integrate the observed and projected climate change impacts into simulations of the electricity system expansion for realizing a climate-resilient electricity system and estimating costs and benefits of adaptation of the power sector to climate change.

The estimation of weather-related damage to the electricity sector in this study is limited to the direct losses suffered by electric utilities, primarily including energy-not-supplied. We also include direct economic losses from damaged assets and equipment when data permits. This study, however, 
does not account for complete economic losses due to weather- and climate-related widespread power cuts. Hence, business interruptions and other cross-sectoral impacts of hazards are out of the scope of this paper.

Author Contributions: K.H., Y.K. and T.F. involved in the conceptualization of research problems and method. K.H. carried out the fieldwork, analyzed the data, and wrote the draft paper. T.F. contributed to writing the final paper. Y.K. and T.F. reviewed the presented findings.

Funding: This research was funded by the Indonesian Endowment Fund for Education (LPDP), grant number PRJ-2570/LPDP/2015.

Acknowledgments: Authors are very grateful to all the respondents who contributed with their knowledge, experience, and time during the fieldwork and afterward. Furthermore, we would like to express our gratitude to PT Perusahaan Listrik Negara, PT Pembangkitan Jawa Bali, PT Indonesia Power, and BMKG for providing secondary data required for our analysis.

Conflicts of Interest: The authors declare no conflict of interest.

\section{Appendix A}

Historical trends and future projection of the Indonesian climate.

Table A1. Historical trends and future projections of the Indonesian climate. Source: $[46,50]$.

\begin{tabular}{|c|c|c|}
\hline Climate Parameters & Historical Trends & Future Projections \\
\hline Temperature & $\begin{array}{l}\text { Mean annual temperature increased } \\
+0.04{ }^{\circ} \mathrm{C} \text { per decade between } 1985 \\
\text { to } 2015\end{array}$ & $\begin{array}{l}\text { Mean annual temperature increase by }+1.1 \text { to }+3.2^{\circ} \mathrm{C} \\
\text { by } 2085 \text { compared to the reference period from } 1971 \\
\text { to } 2000\end{array}$ \\
\hline Heatwaves & $\begin{array}{l}\text { The frequency of hot days and nights } \\
\text { increased by }+88 \text { days and }+95 \text { nights, } \\
\text { respectively between } 1960 \text { and } 2006 \text {. }\end{array}$ & $\begin{array}{l}\text { - The likely increase in the duration of heat waves } \\
\text { ranging from }+23 \text { to }+1340 \text { days by } 2085 \\
\text { compared to the reference period from } 1971 \\
\text { to } 2000 \\
\text { The decrease in the duration of cold spell } \\
\text { ranging from }-10 \text { to }-1 \text { day compared to the } \\
\text { reference period from } 1971 \text { to } 2000\end{array}$ \\
\hline Rainfall & $\begin{array}{l}\text { Average annual rainfall increased by } \\
12 \% \text { from } 1985 \text { to } 2015\end{array}$ & $\begin{array}{l}\text { - Although projections for rainfall differ, they } \\
\text { point to increased rainfall during the wet season } \\
\text { The likely range of projected dry spells is from } 0 \\
\text { to }+2 \text { days compared to the reference period } \\
\text { from } 1971 \text { to } 2000 \\
\text { - Increase in frequency and intensity of heavy } \\
\text { rainfall events by } 3-31 \% \text { and } 2-13 \% \text {, } \\
\text { respectively compared to the reference period } \\
\text { from } 1971 \text { to } 2000\end{array}$ \\
\hline Sea level & $\begin{array}{l}\text { Sea level rise of } 2-10 \mathrm{~mm} \text { per year from } \\
1993 \text { to } 2012\end{array}$ & Sea level rise of $150-450 \mathrm{~mm}$ by 2056 \\
\hline Tropical glacier & $\begin{array}{l}\text { Decreased of tropical Papua glaciers } \\
\text { cover by } 78 \text { percent from } 1936 \text { to } 2006\end{array}$ & The disappearance of Papua glaciers \\
\hline
\end{tabular}

\section{Appendix B}

Table A2. Questions presented to different stakeholders.

\begin{tabular}{|c|c|c|c|}
\hline $\begin{array}{c}\text { Concern of the } \\
\text { Questions }\end{array}$ & No. & Questions & Expected Supporting Documents \\
\hline \multirow[t]{2}{*}{$\begin{array}{l}\text { Head office } \\
\text { representatives }\end{array}$} & 1. & $\begin{array}{l}\text { Based on your experience, how do weather and } \\
\text { climate affect power generation, transmission, and } \\
\text { distribution networks? }\end{array}$ & \\
\hline & 2. & $\begin{array}{l}\text { Have floods ever occurred and impacted the } \\
\text { electricity infrastructure? How often? What was the } \\
\text { cause? Did the infrastructure shut down? How } \\
\text { much was the financial loss? }\end{array}$ & $\begin{array}{l}\text { Documentation of the flooding } \\
\text { SOP of dealing with floods }\end{array}$ \\
\hline
\end{tabular}


Table A2. Cont.

\begin{tabular}{|c|c|c|c|}
\hline $\begin{array}{l}\text { Concern of the } \\
\text { Questions }\end{array}$ & No. & Questions & Expected Supporting Documents \\
\hline & 3. & $\begin{array}{l}\text { What has been done to deal with the floods? How } \\
\text { much do these actions cost? }\end{array}$ & \\
\hline & 4. & $\begin{array}{l}\text { Were there any interruptions on electricity supply } \\
\text { attributable to extreme weather? What and when? } \\
\text { How much were the financial losses? } \\
\text { How did the operation interruption affect the rest of } \\
\text { the economy (in the region/island/country-choose } \\
\text { the relevant)? }\end{array}$ & $\begin{array}{l}\text { Documentation of the operation } \\
\text { interruptions due to extreme weather }\end{array}$ \\
\hline & 5. & $\begin{array}{l}\text { Are there any policies and programs addressing } \\
\text { climate change impact and adaptation? Is there any } \\
\text { budget allocated? }\end{array}$ & $\begin{array}{l}\text { Copy of policies and programs } \\
\$ \$ \text { of investments planned }\end{array}$ \\
\hline \multirow[t]{5}{*}{$\begin{array}{l}\text { Grid operator (load } \\
\text { control center) }\end{array}$} & 1. & $\begin{array}{c}\text { What is the load shape of the Java-Bali } \\
\text { electricity system? } \\
\text { In addition, Jakarta subsystem, West Java subsystem, } \\
\text { Central Java subsystem, East Java subsystem and } \\
\text { Bali subsystem. }\end{array}$ & $\begin{array}{l}\text { At least ten years of hourly-load data } \\
\text { System Operation Evaluation Annual } \\
\text { Reports (at least ten years) }\end{array}$ \\
\hline & 2. & $\begin{array}{l}\text { Has flood ever occurred in the dispatcher units? } \\
\text { How often? What were the causes? Did they cause } \\
\text { power cuts? How much were the financial losses? }\end{array}$ & $\begin{array}{l}\text { Documentation of the flooding } \\
\text { SOP of dealing with floods }\end{array}$ \\
\hline & 3. & $\begin{array}{l}\text { What has been done to deal with the floods? How } \\
\text { much do they cost? }\end{array}$ & \\
\hline & 4. & $\begin{array}{l}\text { Was there any operation interruption due to extreme } \\
\text { weather? What and when? How often? How much } \\
\text { was the financial loss? }\end{array}$ & $\begin{array}{l}\text { Documentation of the operation } \\
\text { interruptions due to extreme weather }\end{array}$ \\
\hline & 5. & $\begin{array}{l}\text { Are there any policies and programs addressing } \\
\text { climate change impact and adaptation? Is there any } \\
\text { budget allocated? }\end{array}$ & Copy of policies and programs \\
\hline \multirow{8}{*}{$\begin{array}{l}\text { Thermal power plants } \\
\text { (coal and gas-based } \\
\text { power plants) }\end{array}$} & 1. & What is the trend of cooling water temperature? & $\begin{array}{l}\text { Monitoring data on cooling water } \\
\text { temperature in last }(5,10,15 \text { years } \\
\text { if possible) }\end{array}$ \\
\hline & 2. & $\begin{array}{l}\text { Is there any correlation between cooling water } \\
\text { temperature and power plant's efficiency? What } \\
\text { and how? }\end{array}$ & $\begin{array}{l}\text { Monitoring data on cooling water } \\
\text { temperature and power } \\
\text { plant's efficiency }\end{array}$ \\
\hline & 3. & $\begin{array}{l}\text { Has the sea level changed from the first year } \\
\text { of operation? }\end{array}$ & Sea level data \\
\hline & 4. & $\begin{array}{l}\text { What has been done to maintain the cooling water } \\
\text { temperature at the desired level? How much does } \\
\text { it cost? } \\
\text { To what extent (in \%?) were you able to recover the } \\
\text { power output to the pre-warming levels? }\end{array}$ & \\
\hline & 5. & $\begin{array}{l}\text { Has flood ever occurred and impacted the power } \\
\text { plants? How often? What was the cause? Did the } \\
\text { plant shut down? How much was the financial loss? }\end{array}$ & $\begin{array}{l}\text { Documentation of the flooding } \\
\text { SOP of dealing with floods }\end{array}$ \\
\hline & 6. & $\begin{array}{l}\text { What has been done to deal with the floods? How } \\
\text { much do these actions cost? }\end{array}$ & \\
\hline & 7. & $\begin{array}{c}\text { Was there any operation interruption due to extreme } \\
\text { weather? What and when? How much were the } \\
\text { financial losses? }\end{array}$ & $\begin{array}{l}\text { Documentation of the operation } \\
\text { interruptions due to extreme weather. }\end{array}$ \\
\hline & 8. & $\begin{array}{l}\text { Are there any policies and programs addressing } \\
\text { climate change impact and adaptation? Is there any } \\
\text { budget allocated? }\end{array}$ & $\begin{array}{l}\text { Copy of policies and programs } \\
\$ \$ \text { of investments planned }\end{array}$ \\
\hline \multirow[t]{4}{*}{$\begin{array}{l}\text { Hydroelectric power } \\
\text { plants }\end{array}$} & 1. & $\begin{array}{c}\text { What is the trend of precipitation and water level? } \\
\text { Has the water level changed from the first year } \\
\text { of operation? }\end{array}$ & $\begin{array}{l}\text { Monitoring data of precipitation, } \\
\text { water inflow, the water level }\end{array}$ \\
\hline & 2. & How does the trend affect electricity production? & $\begin{array}{l}\text { Monitoring data on } \\
\text { electricity production }\end{array}$ \\
\hline & 3. & $\begin{array}{c}\text { Was there any operation interruption due to low } \\
\text { water level/drought or excessive water? How often? } \\
\text { How much were the financial losses? }\end{array}$ & $\begin{array}{l}\text { Water level and electricity } \\
\text { production data }\end{array}$ \\
\hline & 4. & $\begin{array}{l}\text { Have there been any actions done to increase the } \\
\text { water level? What are they? How much do they cost? }\end{array}$ & \\
\hline
\end{tabular}


Table A2. Cont.

\begin{tabular}{|c|c|c|c|}
\hline $\begin{array}{l}\text { Concern of the } \\
\text { Questions }\end{array}$ & No. & Questions & Expected Supporting Documents \\
\hline & 5. & $\begin{array}{l}\text { Has flood ever occurred in the power plants? How } \\
\text { often? What was the cause? Did the plant shut } \\
\text { down? How much was the financial loss? }\end{array}$ & $\begin{array}{l}\text { Documentation of the flooding } \\
\text { SOP of dealing with floods }\end{array}$ \\
\hline & 6. & $\begin{array}{l}\text { What has been done to deal with the floods? How } \\
\text { much do they cost? }\end{array}$ & \\
\hline & 7. & $\begin{array}{l}\text { Was there any operation interruption due to extreme } \\
\text { weather? What and when? How often? How much } \\
\text { were the financial losses? }\end{array}$ & $\begin{array}{l}\text { Documentation of the operation } \\
\text { interruptions due to extreme weather }\end{array}$ \\
\hline & 8. & $\begin{array}{l}\text { Are there any company's policies and programs } \\
\text { addressing climate change impact and adaptation? Is } \\
\text { there any budget allocated? }\end{array}$ & Copy of policies and programs \\
\hline \multirow[t]{4}{*}{ Transmission networks } & 1. & $\begin{array}{l}\text { Has flood ever occurred in substations, and } \\
\text { transmission networks? How often? What were the } \\
\text { causes? Did they cause power cuts? How much were } \\
\text { the financial losses? }\end{array}$ & $\begin{array}{l}\text { Documentation of the flooding } \\
\text { SOP of dealing with floods }\end{array}$ \\
\hline & 2. & $\begin{array}{l}\text { What has been done to deal with the floods? How } \\
\text { much do they cost? }\end{array}$ & \\
\hline & 3. & $\begin{array}{l}\text { Was there any operation interruption due to extreme } \\
\text { weather? What and when? How often? How much } \\
\text { was the financial loss? }\end{array}$ & $\begin{array}{l}\text { Documentation of the operation } \\
\text { interruptions due to extreme weather }\end{array}$ \\
\hline & 4. & $\begin{array}{l}\text { Are there any policies and programs addressing } \\
\text { climate change impact and adaptation? Is there any } \\
\text { budget allocated? }\end{array}$ & Copy of policies and programs \\
\hline \multirow[t]{5}{*}{ Distribution networks } & 1. & $\begin{array}{l}\text { Is there any information about the amount of } \\
\text { electricity use for space cooling? Do you observe any } \\
\text { trends in relationships between T rise and changes in } \\
\text { demand for E (due to cooling)? }\end{array}$ & \\
\hline & 2. & $\begin{array}{l}\text { Has flood ever occurred in distribution substations } \\
\text { and networks? How often? What were the causes? } \\
\text { Did they cause power cuts? How much were the } \\
\text { financial losses? }\end{array}$ & $\begin{array}{l}\text { Documentation of the flooding } \\
\text { SOP of dealing with floods }\end{array}$ \\
\hline & 3. & $\begin{array}{l}\text { What has been done to deal with the floods? How } \\
\text { much do they cost? }\end{array}$ & \\
\hline & 4. & $\begin{array}{l}\text { Was there any operation interruption due to extreme } \\
\text { weather? What and when? How often? How much } \\
\text { was the financial loss? }\end{array}$ & $\begin{array}{l}\text { Documentation of operation } \\
\text { interruptions due to extreme weather }\end{array}$ \\
\hline & 5. & $\begin{array}{l}\text { Are there any policies and programs addressing } \\
\text { climate change impact and adaptation? Is there any } \\
\text { budget allocated? }\end{array}$ & Copy of policies and programs \\
\hline
\end{tabular}

\section{Appendix C}

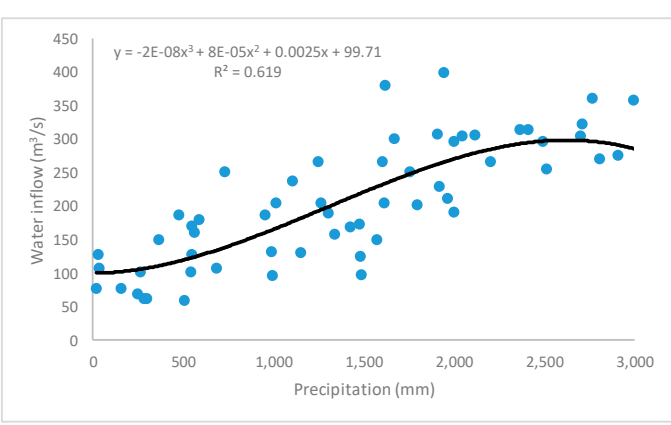

(a)

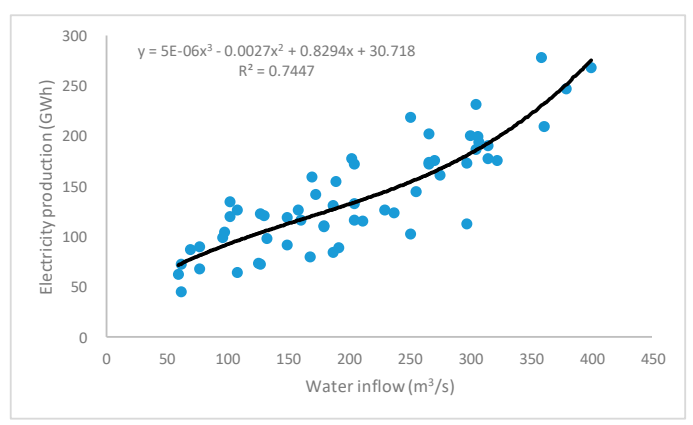

(b)

Figure A1. The correlation between precipitation, water inflow, and electricity production: Cirata HEPP. Source: own analysis. (a) Monthly water inflow as a function of precipitation $1 \mathrm{~F}$ (precipitation data from seven weather stations): Cirata HEPP 2013-2017. (b) Monthly electricity production as a function of water inflow: 2013-2017. 


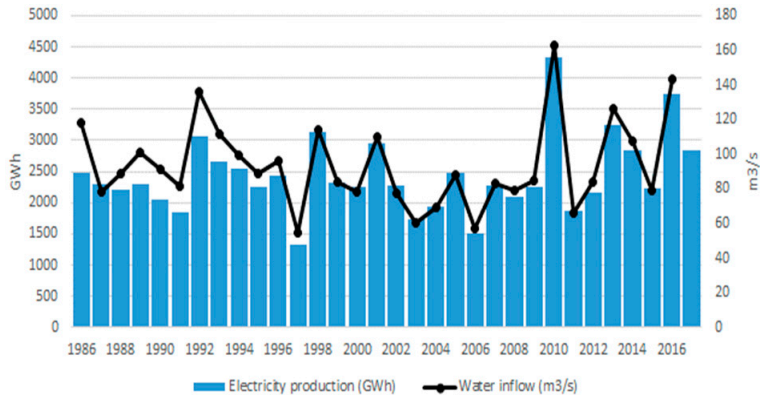

(a)

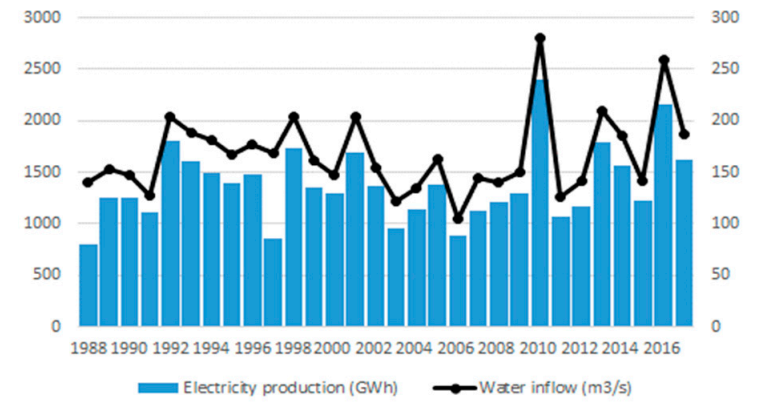

(b)

Figure A2. Historical data on electricity production and water inflow. Source: own fieldwork. (a) Saguling HEPP; (b) Cirata HEPP.

\section{References}

1. World Bank. World Development Report 2010: Development and Climate Change. 2010. Available online: https://siteresources.worldbank.org/INTWDR2010/Resources/5287678-1226014527953/WDR10-FullText.pdf (accessed on 25 June 2019).

2. Hoegh-Guldberg, O.; Jacob, D.; Taylor, M.; Bindi, M.; Brown, S.; Camilloni, I.; Diedhiou, A.; Djalante, R.; Ebi, K.L.; Engelbrecht, F.; et al. Impacts of $1.5^{\circ} \mathrm{C}$ Global Warming on Natural and Human Systems. In Press.

3. Connell, R.; Firth, J.; Baglee, A.; Haworth, A.; Steeves, J.; Fouvet, C.; Hamaker-Taylor, R. Navigating a New Climate. Assessing Credit Risk and Opportunity in a Changing Climate: Outputs of a Working Group of 16 Banks Piloting the TCFD Recommendations; Part 2: Physical risks and opportunities; UN Environment Finance Initiative and Acclimatise Group Ltd.: Geneva, Switzerland, 2018.

4. Mufson, S. Moody's Analytics says climate change could cost \$69 trillion by 2100. Washington Post, 8 July 2019.

5. Naden, C. Managing the Impact of Climate Change: First International Standard for Adaptation Published. Available online: https://www.iso.org/news/ref2405.html (accessed on 25 July 2019).

6. Sieber, J. Impacts of, and adaptation options to, extreme weather events and climate change concerning thermal power plants. Clim. Chang. 2013, 121, 55-66. [CrossRef]

7. Panteli, M.; Mancarella, P. Influence of extreme weather and climate change on the resilience of power systems: Impacts and possible mitigation strategies. Electr. Power Syst. Res. 2015, 127, 259-270. [CrossRef]

8. Ward, D.M. The effect of weather on grid systems and the reliability of electricity supply. Clim Chang. 2013, 121, 103-113. [CrossRef]

9. Cenek, M.; Haro, R.; Sayers, B.; Peng, J. Climate Change and Power Security: Power Load Prediction for Rural Electrical Microgrids Using Long Short Term Memory and Artificial Neural Networks. Appl. Sci. 2018, 8, 749. [CrossRef]

10. Syariman, P.; Heru, A. Extreme Weather Impacts on Citarum Cascade Reservoir Operation Pattern 2011. J. Tek. Hidraul. 2011, 2, 57-68.

11. Nicolas, C.; Rentschler, J.; Potter van Loon, A.; Oguah, S.; Schweikert, A.; Deinert, M.; Koks, E.; Arderne, C.; Cubas, D.; Li, J.; et al. Stronger Power: Improving Power Sector Resilience to Natural Hazards. Sector Note for LIFELINES: The Resilient Infrastructure Opportunity; The World Bank: Washington, DC, USA, 2019.

12. De Lucena, A.F.P.; Schaeffer, R.; Szklo, A.S. Least-cost adaptation options for global climate change impacts on the Brazilian electric power system. Glob. Environ. Chang. 2010, 20, 342-350. [CrossRef]

13. Bartos, M.D.; Chester, M.V. Impacts of climate change on electric power supply in the Western United States. Nat. Clim. Chang. 2015, 5, 748-752. [CrossRef]

14. Henry, C.L.; Pratson, L.F. Effects of environmental temperature change on the efficiency of coal- and natural gas-fired power plants. Environ. Sci. Technol. 2016, 50, 9764-9772. [CrossRef]

15. Popescu, I.; Brandimarte, L.; Peviani, M. Effects of climate change over energy production in La Plata Basin. Int. J. River Basin Manag. 2014, 12, 319-327. [CrossRef]

16. Johnston, P.C.; Gomez, J.F.; Laplante, B. Climate Risk and Adaptation in the Electric Power Sector; Asian Development Bank: Mandaluyong, Philippines, 2012. 
17. Tobin, I.; Greuell, W.; Jerez, S.; Ludwig, F.; Vautard, R.; Van Vliet, M.T.H.; Breón, F.M. Vulnerabilities and resilience of European power generation to $1.5^{\circ} \mathrm{C}, 2{ }^{\circ} \mathrm{C}$ and $3{ }^{\circ} \mathrm{C}$ warming. Environ. Res. Lett. 2018, 13. [CrossRef]

18. Vine, E. Adaptation of California's electricity sector to climate change. Clim Chang. 2012, 111, 75-99. [CrossRef]

19. Li, S.; Coit, D.W.; Selcuklu, S.; Felder, F.A. Electric Power Generation Expansion Planning: Robust Optimization Considering Climate Change. In Proceedings of the 2014 Ind Syst Eng Res Conf, Montreal, QC, Canada, 31 May-3 June 2014; pp. 1-10. [CrossRef]

20. Seljom, P.; Rosenberg, E.; Fidje, A.; Haugen, J.E.; Meir, M.; Rekstad, J.; Jarlset, T. Modelling the effects of climate change on the energy system-A case study of Norway. Energy Policy 2011, 39, 7310-7321. [CrossRef]

21. Van Vliet, M.T.H.; Yearsley, J.R.; Ludwig, F.; Vogele, S.; Lettenmaier, D.P.; Kabat, P. Vulnerability of US and European electricity supply to climate change. Nat. Clim. Chang. 2012, 2, 676-681. [CrossRef]

22. Cook, M.A.; King, C.W.; Davidson, F.T.; Webber, M.E. Assessing the impacts of droughts and heat waves at thermoelectric power plants in the United States using integrated regression, thermodynamic, and climate models. Energy Rep. 2015, 1, 193-203. [CrossRef]

23. De Lucena, A.F.P.; Szklo, A.S.; Schaeffer, R.; de Souza, R.R.; Borba, B.S.M.C.; da Costa, I.V.L.; PereiraJúnior, A.O.; Cunha, S.H.F. The vulnerability of renewable energy to climate change in Brazil. Energy Policy 2009, 37, 879-889. [CrossRef]

24. Jerez, S.; Tobin, I.; Vautard, R.; Montávez, J.P.; López-Romero, J.M.; Thais, F.; Bartok, B.; Christensen, O.B.; Colette, A.; Déqué, M.; et al. The impact of climate change on photovoltaic power generation in Europe. Nat. Commun. 2015, 6, 10014. [CrossRef]

25. Pereira de Lucena, A.F.; Szklo, A.S.; Schaeffer, R.; Dutra, R.M. The vulnerability of wind power to climate change in Brazil. Renew Energy 2010, 35, 904-912. [CrossRef]

26. Kaufmann, R.K.; Gopal, S.; Tang, X.; Raciti, S.M.; Lyons, P.E.; Geron, N.; Craig, F. Revisiting the weather effect on energy consumption: Implications for the impact of climate change. Energy Policy 2013, 62, 1377-1384. [CrossRef]

27. Véliz, K.D.; Kaufmann, R.K.; Cleveland, C.J.; Stoner, A.M.K. The effect of climate change on electricity expenditures in Massachusetts. Energy Policy 2017, 106, 1-11. [CrossRef]

28. Schaeffer, R.; Szklo, A.S.; Pereira de Lucena, A.F.; Moreira Cesar Borba, B.S.; Pupo Nogueira, L.P.; Fleming, F.P.; Troccoli, A.; Harrison, M.; SadeckBoulahya, M. Energy sector vulnerability to climate change: A review. Energy 2012, 38, 1-12. [CrossRef]

29. Pašičko, R.; Branković, Č.; Šimić, Z. Assessment of climate change impacts on energy generation from renewable sources in Croatia. Renew. Energy 2012, 46, 224-231. [CrossRef]

30. Cronin, J.; Anandarajah, G.; Dessens, O. Climate change impacts on the energy system: A review of trends and gaps. Clim Chang. 2018, 151, 79-93. [CrossRef]

31. Bhattacharyya, S.C. A review of energy system models. Int. J. Energy Sect. Manag. 2010, 4, 494-518. [CrossRef]

32. Audinet, P.; Amado, J.-C.; Rabb, B. Climate Risk Management Approaches in the Electricity Sector: Lessons from Early Adapters; Springer: Berlin/Heidelberg, Germany, 2014; pp. 17-64.

33. IPCC. Glossary of Terms. In Managing the Risks of Extreme Events and Disasters to Advance Climate Change Adaptation; Field, C.B., Barros, V., Stocker, T.F., Qin, D., Dokken, D.J., Ebi, K.L., Mastrandrea, M.D., Mach, K.J., Plattner, G.-K., Allen, S.K., Eds.; Cambridge University Press: Cambridge, UK; New York, NY, USA, 2012.

34. UNFCCC. Climate Change: Impacts, Vulnerabilities and Adaptation in Developing Countries. 2007. Available online: http://unfccc.int/resource/docs/publications/impacts.pdf (accessed on 30 November 2018).

35. Clarke, L.; Sokka, L.; Jiang, K.; Akimoto, K.; Babiker, M.; Blanford, G.; Fisher-Vanden, K.; Hourcade, J.; Krey, V.; Kriegler, E.; et al. Assessing Transformation Pathways Coordinating Lead Authors: Chapter Science Assistant. In Climate Change 2014: Mitigation of Climate Change. Contribution of Working Group IIIto the Fifth Assessment Report of the Intergovernmental Panel on Climate Change; Cambridge University Press: Cambridge, UK, 2014; p. 98.

36. World Bank. The World Bank in Indonesia. Available online: https://www.worldbank.org/en/country/ indonesia/overview (accessed on 3 September 2019). 
37. Government of The Republic of Indonesia. First Nationally Determined Contribution Republic of Indonesia 2016. Available online: http://www4.unfccc.int/ndcregistry/PublishedDocuments/IndonesiaFirst/ FirstNDCIndonesia_submittedtoUNFCCCSet_November2016.pdf (accessed on 12 January 2017).

38. IEA. World Energy Outlook 2018: Electricity. 2018. Available online: https://www.iea.org/sdg/electricity/ (accessed on 17 July 2019).

39. IEA. World Energy Balances 2018. Available online: https://webstore.iea.org/world-energy-balances-2018 (accessed on 20 February 2019).

40. PWC. Power in Indonesia: Investment and Taxation Guide November 2017 5th Edition. 2017. Available online: https://www.pwc.com/id/en/energy-utilities-mining/assets/power/power-guide-2017.pdf (accessed on 19 November 2018).

41. BPS. Statistical Yearbook of Indonesia 2018. 2018. Available online: https://www.bps.go.id/publication/2018/ 07/03/5a963c1ea9b0fed6497d0845/statistik-indonesia-2018.html (accessed on 30 May 2019).

42. PLN. Electricity Supply Bussiness Plan (RUPTL) 2018-2027. 2018. Available online: http://www.pln.co.id/ stakeholder/ruptl (accessed on 18 June 2018).

43. PLN. Statistik PLN 2018. Available online: https://www.pln.co.id/statics/uploads/2019/07/Buku-Statistik2018-vs-Indo-Final.pdf (accessed on 19 November 2018).

44. KESDM. Statistik Ketenagalistikan 2016. 2017. Available online: https://www.esdm.go.id/assets/media/ content/content-statistik-ketenagalistrikan-tahun-2016-1.pdf (accessed on 26 July 2018).

45. PLN. Statistik PLN 2016. Available online: https://www.pln.co.id/statics/uploads/2017/05/Statistik2016.pdf (accessed on 18 April 2018).

46. USAID. Climate Risk Profile Indonesia. 2017. Available online: https://www.climatelinks.org/resources/ climate-risk-profile-indonesia (accessed on 23 October 2018).

47. BAPPENAS. Rencana Aksi Nasional Adaptasi Perubahan Iklim (RAN-API). 2014. Available online: http://sekretariat-ranapi.org/storage/app/media/RAN-API.pdf (accessed on 03 February 2016).

48. Timmermann, A.; Oberhuber, J.; Bacher, A.; Esch, M.; Latif, M.; Roeckner, E. Increased El Nino frequency in a climate model forced by future greenhouse warming. Nature 1999, 398, 694-697. [CrossRef]

49. BAPPENAS Indonesia Climate Change Sectoral Roadmap_ICCSR Scientific Basis: Analysis and Projection of Sea Level Rise and Extreme Weather Events. 2010. Available online: https:/www.bappenas.go.id/files/2013/ 5229/9917/analysis-and-projection-of-sea-level-rise-and-extreme-weathe_20110217130224_1.pdf (accessed on 03 February 2016).

50. GERICS. Indonesia Climate-Fact-Sheet. 2015. Available online: https://www.climate-service-center.de/index. php.en\#Region-Asia-Indonesia (accessed on 19 November 2018).

51. Dutch Sustainability Unit. Climate Change Profile: INDONESIA. 2016. Available online: http://api. commissiemer.nl/docs/os/i71/i7196/climate_change_profile_indonesia_2016_reduced_size.pdf (accessed on 19 November 2018).

52. World Bank. Vulnerability, Risk Reduction and Adaptation to Climate Change: Indonesia. 2011. Available online: http://sdwebx.worldbank.org/climateportalb/doc/GFDRRCountryProfiles/wb_gfdrr_ climate_change_country_profile_for_IDN.pdf (accessed on 20 November 2018).

53. IPCC. Glossary. In Climate Change 2014: Impacts, Adaptation, and Vulnerability. Contribution of Working Group II to the Fifth Assessment Report of the Intergovernmental Panel on Climate Change. Available online: https://www.ipcc.ch/site/assets/uploads/2018/02/WGIIAR5-AnnexII_FINAL.pdf (accessed on 3 September 2019).

54. Damayanty, D. Membenahi Perusahaan Listrik Negara. Available online: https://sains.kompas.com/read/ 2008/01/10/19315174/membenahi.perusahaan.listrik.negara (accessed on 24 May 2018).

55. Tanjung Jati. Tanjung Jati B Dimatikan. MerdekaCom. 2007. Available online: https://www.merdeka.com/ uang/pasokan-batubara-terganggu-pltu-tanjung-jati-b-dimatikan-5brucri.html (accessed on 13 June 2018).

56. Detikfinance. Pasokan Batubara Seret, PLN Tambah Pemakaian BBM. DetikCom. 2007. Available online: https://finance.detik.com/berita-ekonomi-bisnis/d-752626/pasokan-batubara-seret-pln-tambahpemakaian-bbm (accessed on 24 May 2018).

57. Rafiq, M. BMKG sebut Perubahan Iklim Dingin Sebabkan Migrasi Ubur-ubur ke Laut Utara Jawa. DetikCom. 2016. Available online: https://news.detik.com/berita-jawa-timur/3201707/bmkg-sebut-perubahan-iklimdingin-sebabkan-migrasi-ubur-ubur-ke-laut-utara-jawa/komentar (accessed on 13 June 2018). 
58. Purcell, J.E. Climate effects on formation of jellyfish and ctenophore blooms: A review. J. Mar. Biol. Assoc. UK 2005, 85, 461-476. [CrossRef]

59. Aljbour, S.M.; Zimmer, M.; Al-Horani, F.A.; Kunzmann, A. Metabolic and oxidative stress responses of the jellyfish Cassiopea sp.to changes in seawater temperature. J. Sea Res. 2019, 145, 1-7. [CrossRef]

60. Musim Kering. Musim Kering, PLTA Saguling Cirata Hanya Beroperasi Malam Hari. DetikCom. 2011. Available online: https:/finance.detik.com/energi/d-1726926/musim-kering-plta-saguling-cirata-hanyaberoperasi-malam-hari (accessed on 11 June 2018).

61. BMKG. Temperature Data 2014. 2018. Available online: http://dataonline.bmkg.go.id/ (accessed on 2 February 2018).

62. IP Semarang. Addendum ANDAL and RKL-RPL Development and Operational PLTU/PLTGU/PLTG Unit Updates from 1,350 MW become 2,150 MW PT. INDONESIA POWER UP Semarang; PT Indonesia Power: Semarang, Indonesia, 2017.

63. Kates, R.W.; Travis, W.R.; Wilbanks, T.J. Transformational adaptation when incremental adaptations to climate change are insufficient. Proc. Natl. Acad. Sci. USA 2012, 109, 7156-7161. [CrossRef]

(C) 2019 by the authors. Licensee MDPI, Basel, Switzerland. This article is an open access article distributed under the terms and conditions of the Creative Commons Attribution (CC BY) license (http://creativecommons.org/licenses/by/4.0/). 